Journal

of Geography,

Politics and Society

(2)

$10(2) / 2020$

\section{Journal of Geography, Politics and Society}

2020, 10(2), 35-44

https://doi.org/10.26881/jpgs.2020.2.05

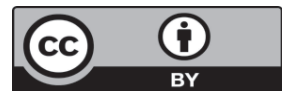

\title{
AGRICULTURE IN GEORGIA - THE CONDITION OF THE SECTOR AND ITS IMPORTANCE IN THE PROCESS OF SOCIO-ECONOMIC DEVELOPMENT OF THE COUNTRY AND ITS REGIONS
}

\author{
Julia Kaczmarek-Khubnaia \\ Faculty of Human Geography and Planning, Adam Mickiewicz University, Krygowskiego 10, 61-680 Poznań, Poland, ORCID: 0000-0001-9749-8295 \\ e-mail: khubnaia@amu.edu.pl
}

\section{Citation}

Kaczmarek-Khubnaia J. 2020, Agriculture in Georgia - the condition of the sector and its importance in the process of socioeconomic development of the country and its regions, Journal of Geography, Politics and Society, 10(2), 35-44.

\begin{abstract}
Due to natural conditions (favourable climate and soil conditions) and the agrarian tradition, the agricultural sector in Georgia has a significant growth potential. Despite the fact that almost $40 \%$ of the population work in the agricultural occupations, this branch is not a priority for the Georgian economy. Literature, strategic documents prepared by the authorities of the country and the available statistical data indicate numerous problems blocking the development of the sector, thus inhibiting the development of the country and its regions, largely inhabited by the rural population. The aim of the study is to present the condition of the agricultural sector and its importance in the process of socio-economic development of Georgia and its regions. The survey was expanded with the analysis of demographic data for the rural areas in Georgia.
\end{abstract}

\section{Key words}

agriculture, rural areas, socio-economic development, Georgia.

\section{Introduction}

Political and economic changes that have occurred in Georgia in recent decades (after regaining the country's independence in 1991), have brought a positive effect, which is confirmed by the available statistical data, e.g. the value of the Gross Domestic Product (GDP) per capita in Georgia (Fig. 1). Despite the initial fluctuations in the value of the rate in the first phase of the political transformation (i.e. in the years 1991-1999), reflecting the difficult and unstable social and economic situation in Georgia in the 1990 s, since 2000 , its value has been gradually increasing. The exceptions are the years: 2009 and 2015.

In 2009 the decline in the ratio was associated with the onset of the 2008-2009 global economic crisis. Moreover, in 2008 in Georgia there was a war that by intensifying the migration of the Georgian population from the breakaway regions to the central part of the country, directly contributed to the rise in unemployment. And the drop in the GDP per capita rate in 2015 resulted from a significant depreciation of the Georgian currency compared to the US 


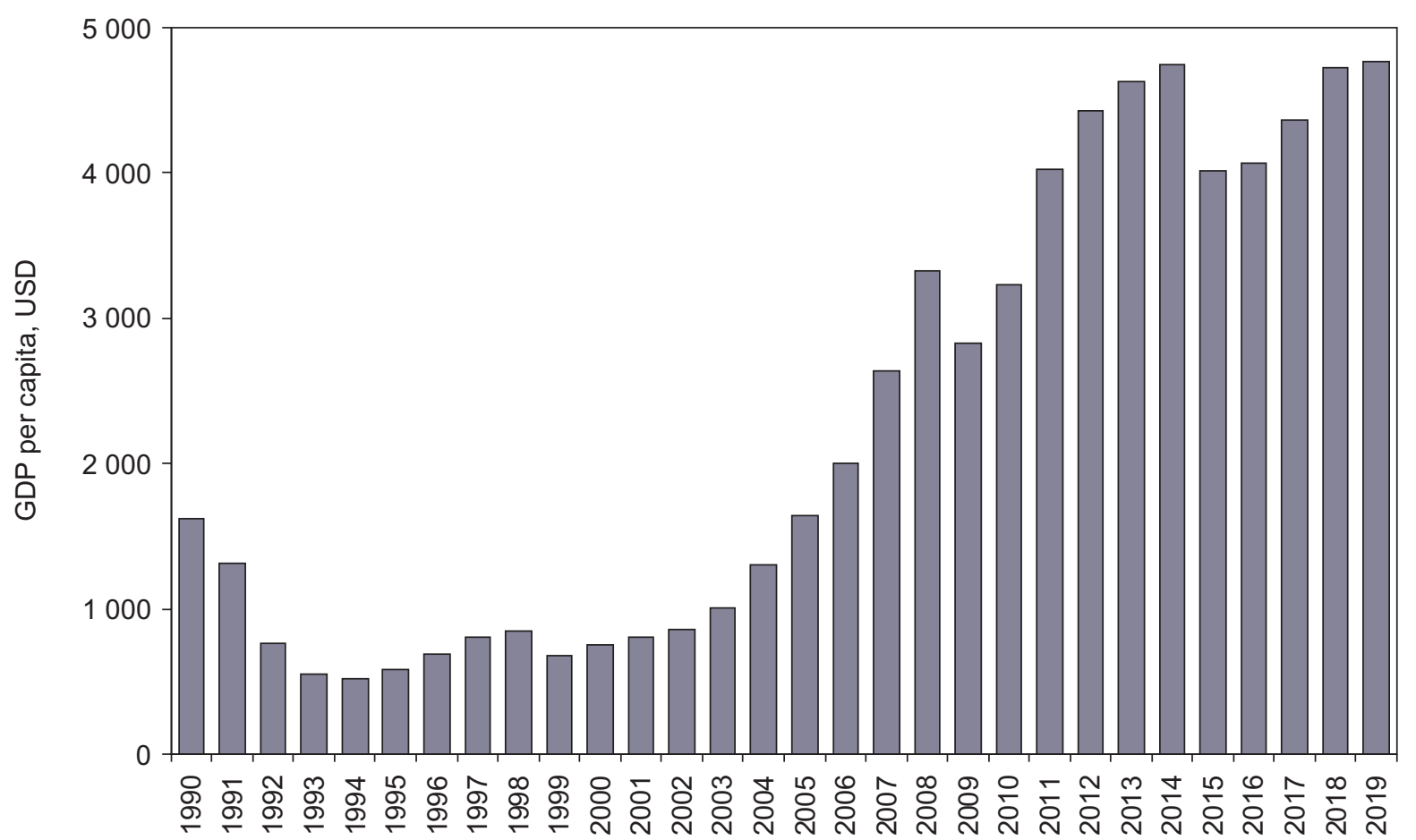

Fig. 1. Gross Domestic Product of Georgia in the years 1990-2019, per capita (USD)

Source: own elaboration based on the World Bank data.

dollar (29\%). This fact is confirmed by the lack of the above-mentioned drop in the case of the GDP per capita rate in 2015 expressed in the national currency (Mzhavanadze, Saha, 2016).

Despite a number of good decisions of the government that increased socio-economic development of the country exhibited by available economic indicators, Georgia is still undergoing transformation processes (Gvindadze, 2017; Papava, 2013; Brodowski, 2019; BTI..., 2020). In many cases, the reforms appear to be insufficient. For example, the unemployment rate in 2019 totalled $11.6 \%$ and its value since 2012 is falling annually. Independent sociological research conducted in Georgia mentioned in a publication by V. Papava (2013) showed, however, that approx. $70 \%$ of questioned citizens considered themselves as unemployed (most of them $(55 \%)$ are self-employed, but their incomes are so low that they do not consider them as a form of income)'. In 2018, the percentage share of the population of Georgia living under absolute poverty line was $20.1 \%$. For the sake of comparison, in 2004 this share was $34.3 \%$. The economic situation of the inhabitants has improved in the last few years, but the number of people living in extreme poverty is still too high to assess the current situation positively. The scale of the problem of poverty is also confirmed by the observations and surveys carried

\footnotetext{
1 In the period described by Papava (publication of 2013) the unemployment rate for Georgia was $15 \%$.
}

out in the rural areas of Georgia by the author of this study. Due to the low value of pension benefits, the oldest group in the population (retired people) have often defined themselves as unemployed, still looking for gainful employment. As indicated by the Georgian researchers (Kharaishvili et al. 2015) 55\% of the country's poor population lives in rural areas.

An important problem in the process of shaping the sustainable development of the country is strong differentiation in the level of development of the Georgian regions. Disparities are most apparent when comparing the capital and the regions in which the largest cities of the country are located (Batumi, Kutaisi) and the rest of the country. Differences in the level of socio-economic development shown in the values of GPD per capita or average earnings of the inhabitants of individual regions affect the size and direction of internal migration, as well as the process of depopulation of the poorest areas, i.e. mountain and peripheral areas (RodriquezPose, Hardy, 2017; Analysis..., 2016; Fuenfzig, 2013). Furthermore, above differences are visible in the level of poverty of the regions (Welton (ed.), 2013).

In view of this continuing difficult economic situation of the inhabitants of the country (as shown by the statistics mainly for rural areas) it is reasonable to conduct in-depth, multi-dimensional analysis of the socio-economic development of Georgia. References to individual sectors of the economy allow for the detailed identification of the shortcomings of the system, i.e. those areas of the country which 
require reform. They are also helpful in the identification of the sectors with the biggest impact and the greatest "potential" in the development process of the country.

On the one hand, available macroeconomic data suggest that agriculture is not currently one of the most important economic sectors of Georgia. For example, the largest share in the structure of the national GDP in 2018 was recorded for trade ${ }^{2}$ (13.9\%), real estate activities (11.4\%) and manufacturing (10.2\%). On the other hand, however, taking into account the fact that approx. $40 \%$ of the population of the country is significantly involved in the agricultural sector (rural areas are inhabited by more than $40 \%$ of the population and almost $40 \%$ works in agriculture), it is justified to analyse its condition and the impact it can have on development processes.

\section{Main objective and scope}

The main aim of the study is to present the condition of the agricultural sector and its importance in the process of socio-economic development of Georgia and its regions. In order to provide a broader context, the study included the demographic characteristics of Georgian rural areas, which significantly determine the current condition of the studied industry.

The spatial scope covers the territory of Georgia, with the exception of breakaway regions, i.e. Abkhazia and South Ossetia ${ }^{3}$. Moreover, the studies partially disregard the capital of Georgia, Tbilisi, which despite its special status of a city/region de facto has a marginal impact on the Georgian agricultural sector. The data for the capital city were quoted only where it was necessary for the proper understanding of the processes occurring in Georgia, e.g. demographic conditions or the employment structure ${ }^{4}$.

\section{Methods and data}

As part of the research, selected statistical methods were mainly used, consisting in the description and relativization of quantitative data (macroeconomic

\footnotetext{
2 Wholesale and retail trade, repair of motor vehicles, motorcycles and personal and household goods.

3 This area is not covered by analysis due to no access to statistical data.

4 The presentation by the Georgian Statistical Office of data on the capital city on a par with the other regions causes that due to the economic importance or population density of Tbilisi, aggregate data often differ significantly from the statistics for individual regions. The situation hinders the proper evaluation of the situation.
}

and agricultural) on a national and regional scale. In addition, the desk research method was used (during the analysis of strategic documents or legal acts) and graphic methods of presenting statistical data.

The article was enriched with the characteristics of the population situation in rural areas, based on the presentation of basic demographic measures.

The author of the article used secondary data sources. Unless otherwise indicated, all data quoted by the author in the study originate from the website of the National Statistics Office of Georgia (Geostat). Because of the gaps in regional statistics (part of the data is aggregated which makes them unusable for the purpose of this study), analysis was based primarily on the results of the General Population Census 2014 and the Agricultural Census 2014, but where possible, this timeframe was extended. Moreover, strategic documents (e.g. Analysis of Regional Disparities in Georgia) and legal act (Law of Georgia on General Education) were examined.

\section{Demographic characteristics of Georgian rural areas}

The population of the rural areas in Georgia in the last quarter century decreased by $34.2 \%{ }^{5}$. At the beginning of 2019, the rural areas of Georgia had a population of 1.54 million people $(41.3 \%$ of the total population). In 1994, at the beginning of the presidency of Eduard Shevardnadze, in the period of the actual economic decline of the country, the number of rural population was 2.28 million $(46.2 \%$ of the total population) ${ }^{6}$. Data for previous years, dating back to the time of affiliation of Georgia to the Russian Empire and the Soviet Union, clearly show that the reduction of the share of the rural population in the population of the studied country with a simultaneous significant increase in the level of urbanisation is a long-term process (Fig. 2).

The capital and the largest city of the country - Tbilisi is characterised by the smallest share of the rural population?. In 2019, it was inhabited by

\footnotetext{
5 The decrease in the number of urban population in the years $1994-2019$ was $17.7 \%$.

6 This period was characterised by a lack of political and economic stability. Long power outages, corruption, widespread poverty and the resulting criminalisation of the society have become the everyday reality for the inhabitants. Even small farms, due to the possibility of food production, often saved the lives of their owners. To this day, residents of Georgian cities and towns, remembering this period mention that having family or friends in the country was often the only chance to survive the first years of transition.

7 The largest increase in the share of rural population in Tbi-
} 


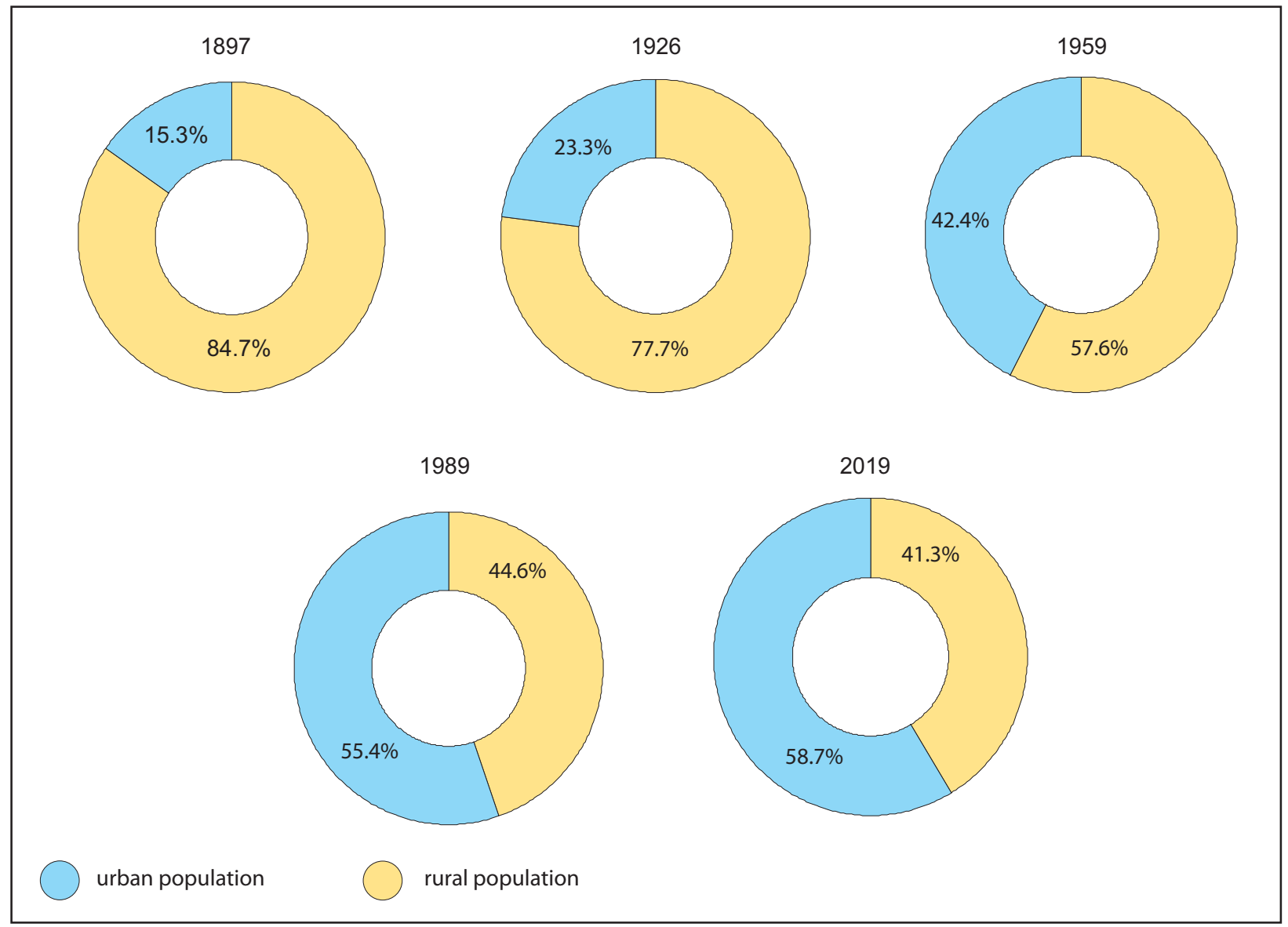

Fig. 2. Percentage share of the rural population in the total population of Georgia in the years 1897-2019

Source: own elaboration based on GEOSTAT data.

1.17 million people, i.e. approx. $31.4 \%$ of the total population. It is worth noting that in 1994, the residents of Tbilisi accounted for a quarter of the population of the country. The movement of people (largely rural) from regions to the capital has for years been influenced by many factors, from economic issues (a greater chance of finding a job, higher earnings) to political conditions (the influx of displaced persons from Abkhazia and South Ossetia). The second region mostly inhabited by the urban population (56.6\% of total population) is coastal Adjara ${ }^{8}$.

In other regions on average more than half of the population now lives in rural areas. In the east of the country, in Kakheti, since Soviet times regarded as

lisi from $0.01 \%$ to $2 \%$ occurred in 2007 . This exception was associated with a change in the borders of regions. The rural population growth in the capital city by approx. 37 thousand people was caused the incorporation of the territories previously belonging to Mtskheta-Mtianeti and Kvemo Kartli. To a large extent, these were areas involved in agriculture.

8 The region in which in subsequent years the urban population may exceed $50 \%$ is Imereti. Currently it is sligthly dominated by the rural population (its share in the total population is $50.8 \%$ ) "the agricultural heart of Georgia", the share of the rural population is as much as $77.3 \%$.

The natural increase rate in Georgia in 2018 amounted to $1.2 \%$ o (2.5\%o for cities and - 0.6\%o for rural areas). This demonstrates the shrinking of rural communities where currently the number of deaths exceeds the number of births. For the sake of comparison, in 1995 the rate for rural areas was positive and amounted to $0.5 \%$. In regional terms, the highest value of the rate in 2018 was recorded in Tbilisi (6.34\%o) and Adjara (6.24\%o), and the lowest in Racha-Lechkhumi and Kvemo Svaneti (-11.3\%o), and Imereti $(-5.06 \%$ ). As many as 7 out of 11 regions covered by the analysis were characterised by negative population growth in rural areas, and in the mid1990s this problem concerned 5 regions. The largest increase during this period was observed in Adjara $(9.6 \%)$ and Kvemo Kartli (6.3\%o), and the lowest in Racha-Lechkhumi and Kvemo Svaneti (-14.7\%o), and Imereti $(-3.3 \% 0)$. This means that the problem of depopulation of the rural areas is deepening over the years. 
The most numerous age groups in the Georgian rural areas in $2014^{9}$ were: (1) people from the youngest group i.e. under 25 years of age whose share in the rural population amounted to $30.1 \%$, and (2) people from the oldest group in the population i.e. above 65 years of age ( $16.3 \%$ of the total population $)^{10}$. The data in the regional breakdown show that most regions were dominated by people under 25 years of age (the largest share was recorded in Kvemo Kartli and Adjara). An exception is Racha-Lechkhumi and Kvemo Svaneti where the most numerous group of residents were people over 65 years of age. It is worth noting that highlander community for many years struggling with the negative effects of depopulation caused by difficult living conditions (poor transport, accessibility especially in the wintertime, unemployment and natural conditions such as terrain, climate).

With regard to the gender structure, a larger group in the rural areas were women, although their number slightly outnumbered males (the difference was $0.2 \%)$. For comparison, in the Georgian cities in 2014 , women accounted for $53.8 \%$ of the total population. In most regions the percentage share of men and women was balanced and accounted for approx. $50 \%$. The regions little dominated by men included: Mtskheta-Mtianeti (51.1\% of the total population), Adjara (50.1\%) and Kvemo Kartli (50.1\%).

In 2014, the rural areas in all regions of Georgia were dominated by complete general education ${ }^{11}$ (i.e. secondary education; $44.7 \%$ of the total population). Other most common indications of respondents were vocational $(17.5 \%)$, higher (13.6\%) and basic education (11.6\%). The least people living in Georgian villages have no education (3.5\%) or education at the primary level $(7.1 \%) .^{12}$ This seemingly positive condition is largely the fruit of the reform of the communist era and the universal combating illiteracy, which is continued until today. It should, however, be noted that the quality of education in the areas of Georgian villages and cities is significantly

\footnotetext{
9 Data on the age, gender and education structure of the rural population are from the last agricultural census conducted in 2014. Yearbooks and publications from later years do not include data broken down by region or information contained in them is highly aggregated, making it impossible to compare all regions.

10 People in the age groups over 55-64 and 65 account for $29.6 \%$.

11 Under the "Law of Georgia on General Education" (2005), there are three levels of general education: primary education (six years), basic education (three years) and secondary education (three years).

12 The remaining $2.1 \%$ are: illiterates $(0.7 \%)$ and people who did not state the level of their education (1.4\%).
}

different, which is mainly caused by a lower level of knowledge of rural teachers. Many students who want to continue their education at universities, before the exam of maturity must use the help of tutors or attend private compensatory courses, which, due to widespread poverty, are unattainable for many of them (Chankseliani, 2013).

In addition, the level of education and the scope of knowledge possessed by the inhabitants of the Georgian rural areas is insufficient to apply the latest technologies and innovation in their farms (Kharaishvili et al., 2015).

The region with the highest number of people with higher education in rural area was RachaLechkhumi and Kvemo Svaneti $(17.2 \%$ of the total population), while the largest share of people with no education was recorded in: Kvemo Kartli (5.5\% of total population) and Samtskhe-Javakheti (4.6\%).

\section{Condition of the agricultural sector and its importance in the process of development of Georgia and its regions}

The agricultural sector in Georgia was significantly modernised during the affiliation of Georgia to the Soviet Union. Moreover, it was subject to collectivisation. The need for change was the result of, among others, a low ${ }^{13}$ level of mechanisation of agriculture, small acreage of arable land and strong fragmentation of farms. Despite the favourable climatic and soil conditions, the presence of mountains and areas that require drainage (e.g. the marshes of Colchis) or hydration (e.g. the area of Kakheti), caused that in terms of agriculture it was difficult for the Georgian Soviet Socialist Republic to catch up with other union republics, for example Ukraine, whose natural conditions contribute to the development of this sector (Bondyrev et al., 2015; Tielidze, 2019). However, Georgia found its niche. An important role in that period was also played by coastal cultivation, in particular of tea (approx. 95\% of the entire USSR) and citrus fruits. Furthermore, viniculture was very popular in the eastern part of the country (Dawitaj (ed.), 1967; Maryański, 1987).

After regaining independence, Georgia was subject to numerous structural reforms, including those related to agriculture. Collective and state farms were replaced by private farms. In the absence of demand, because of the low quality of Georgian brands the production of tea very popular in the Soviet times was reduced (Seturi,Todua, 2019).

13 compared to other union republics. 
The weaknesses of modern agriculture in Georgia are noticed by its authorities. The strategic document "Regional Development Programme of Georgia" for the years 2018-2021 points out, among others, the following issues:

- small acreage of arable lands;

- low level of agriculture modernisation (old machinery, agriculture equipment and technologies);

- absence of logistic;

- high level of self-employment in rural areas (Regional..., 2017).

The above factors inhibit the development of the agricultural sector, thus negatively affecting the socioeconomic development of individual regions and the entire country.

The "Rural Development Strategy of Georgia" for the period 2017-2020 emphasises that the rural areas have an important role in shaping the sustainable development of the country. As with the previously mentioned programme, the strategy refers to the issues of insufficient use of technology and knowledge, and poor condition of farm machinery. Moreover, the authors mention low productivity of the agricultural sector, inadequate access to funding, unemployment in rural areas and growing disparities in the standard of living of the inhabitants of urban and rural areas (Rural..., 2017).

The information contained in both documents indicates that the Georgian agricultural sector is currently confronted with many problems which often greatly reduce the quality of life of people living in the rural areas. The statistics presented later in the study are to illustrate the current condition of the Georgian agriculture and its importance in the development of Georgia and its regions.

In 2004, agriculture land occupied 3,035.8 thousand ha, which accounted for $43 \%$ of the country. $25 \%$ (767.3 thousand ha) of its area was privately owned $^{14}$. There is the issue of a formal census of agriculture land as only $20-30 \%$ of the land used by agriculture is officially registered (Kharaishvili et al., 2015).

The structure of agricultural land in Georgia in 2004 was dominated by pastures (approx. 59.5\%), and it is worth stressing that a significant majority of them was owned by the state (95.3\%). The results of the agricultural census of 2014 indicate that private farms comprised 842.3 thousand ha, of which 787.7 thousand ha had the status of so-called agriculture land. In 10 years (i.e. between 2004 and 2014), the surface area of private agricultural land increased by 20.4 thousand ha. Most of the land forming part of

14 approx. $11 \%$ of the country. private agriculture holding in 2014 included arable land $(47.9 \%)$, and natural meadows and pastures $(38.0 \%)^{15}$. An exception was the region Adjara with the leading role of permanent crops $(45.7 \%$ of the total land used by agriculture). The biggest percentage share of arable land in the total agriculture land in the region was recorded in Imereti (77.6\%), one of the most developed regions of the country. With regard to natural meadows and pastures the largest share was recorded in Samtskhe-Javakheti (61.5\%) and Kvemo Kartli (57.3\%).

The size structure analysis showed that in 2014 as much as $73 \%$ of the Georgian farms had a surface area of less than 1 ha. There were only 954 large farms, i.e. with more than 100 ha, representing only $0.2 \%$ of the Georgian farms. Interestingly, $57.8 \%$ of them were located in Kakheti. The regions with the lowest number of the largest farms were: Adjara ( $0.2 \%$ of all the biggest farms in the country), Racha-Lechkhumi and Kvemo Svaneti $(0.4 \%)$, and Guria (0.7\%). Given the nature of the ownership of farms, Georgia is dominated by households (approx. 99.6\%). These data indicate that the Georgian agriculture is characterised by a strong fragmentation of farms and marginal share of agricultural enterprises (managed by local entities). The small size of farms adversely affects mechanisation and productivity. The virtual lack of large companies means that agriculture is not a lucrative business in Georgia, but rather a way to survive for small family farms, as evidenced by the marginal involvement of foreign investors in the sector analysed. The share of agriculture and fishing in the value of Foreign Direct Investment in $2019^{16}$ was the lowest considering the remaining sectors of the economy, and amounted to approx. $1.1 \%$.

The mountainous topography of Georgia strongly hampers cultivation (the lowland zone occupies only $46 \%$ of its territory). Data from 2014 on the number of wheel, caterpillar or mini tractors (machinery having a higher degree of sophistication) per 100 ha of agriculture land show that the regions with the highest level of agricultural mechanisation were: Shida Kartli, for which the above ratio was 5.1, and Samtskhe-Javakheti (3.0). The value of the indicator for the country (1.7) proves that the Georgian agriculture is characterised by a low level of mechanisation. The problem concerns not only high mountains, but also plains. Despite many reforms, insufficient technical equipment continues since Soviet times. This situation is not solely due to terrain, but also (and in many

\footnotetext{
15 Available data concern on private property only. Taking into account the structure of all agricultural land in Georgia, as in 2004, pastures certainly had the greatest share.

16 Preliminary data.
} 
cases primarily) the difficult economic situation of the rural population.

The value of Gross Domestic Product (GDP) generated by agriculture, forestry and fishing in 2018 amounted to GEL 3,015.9 million, which accounted for approx. $7.8 \%$ of the GDP of the country. Statistics for previous years and the most recent pre-published data for $2019^{17}$ indicate that despite the moments in which the share of the agricultural sector in GDP increased, e.g. in 2010, the general trend should be regarded as declining (Fig. 3.).

The phenomenon of decreasing percentage share of agriculture in the GDP of the country, as noted J. Bański (2007), testifies to its slower pace of development in relation to other, non-agricultural sectors of the economy. This means that its impact on the economy of the country is becoming more and more limited.

With respect to the GDP in the individual regions, the highest percentage of the agricultural sector in 2018 was recorded in the typically agricultural Kakheti (36.7\%), Shida Kartli (25.0\%) and SamtskheJavakheti (22.4\%), and the lowest in Adjara (4.2\%), interestingly one of the most developed region of the country (Fig. 4).
In 2018, the output value in the agricultural sector amounted to GEL 510 million, which accounted for only $1.2 \%$ of Georgia's total production. Since 1999, the share of agricultural production in the total production of Georgia is negligible, ranging between $0.4 \%$ and $1.2 \% .^{18}$

In regional terms, the largest proportion of agricultural production in the total value of production was recorded in the poorly economically developed, mountainous Racha-Lechkhumi and Kvemo Svaneti (on average 10.2\%) and Kakheti (on average approx. 7.4\%).

Agricultural production is dominated by animal breeding, which is associated with topography and a high proportion of pastures in the structure of lands used by agriculture. This is a positive phenomenon as "products of animal origin with a higher degree of processing achieve relatively higher prices than products of plant origin" (Bański, 2006, p. 101). The dominance of livestock production is characteristic for the highly developed countries.

Particularly noteworthy are data on the share of income from the sale in the total income of agriculture household, which in 2018 amounted to only 5.5\% (on average GEL 57.4 per month). Taking into account the average monthly income in Georgia in

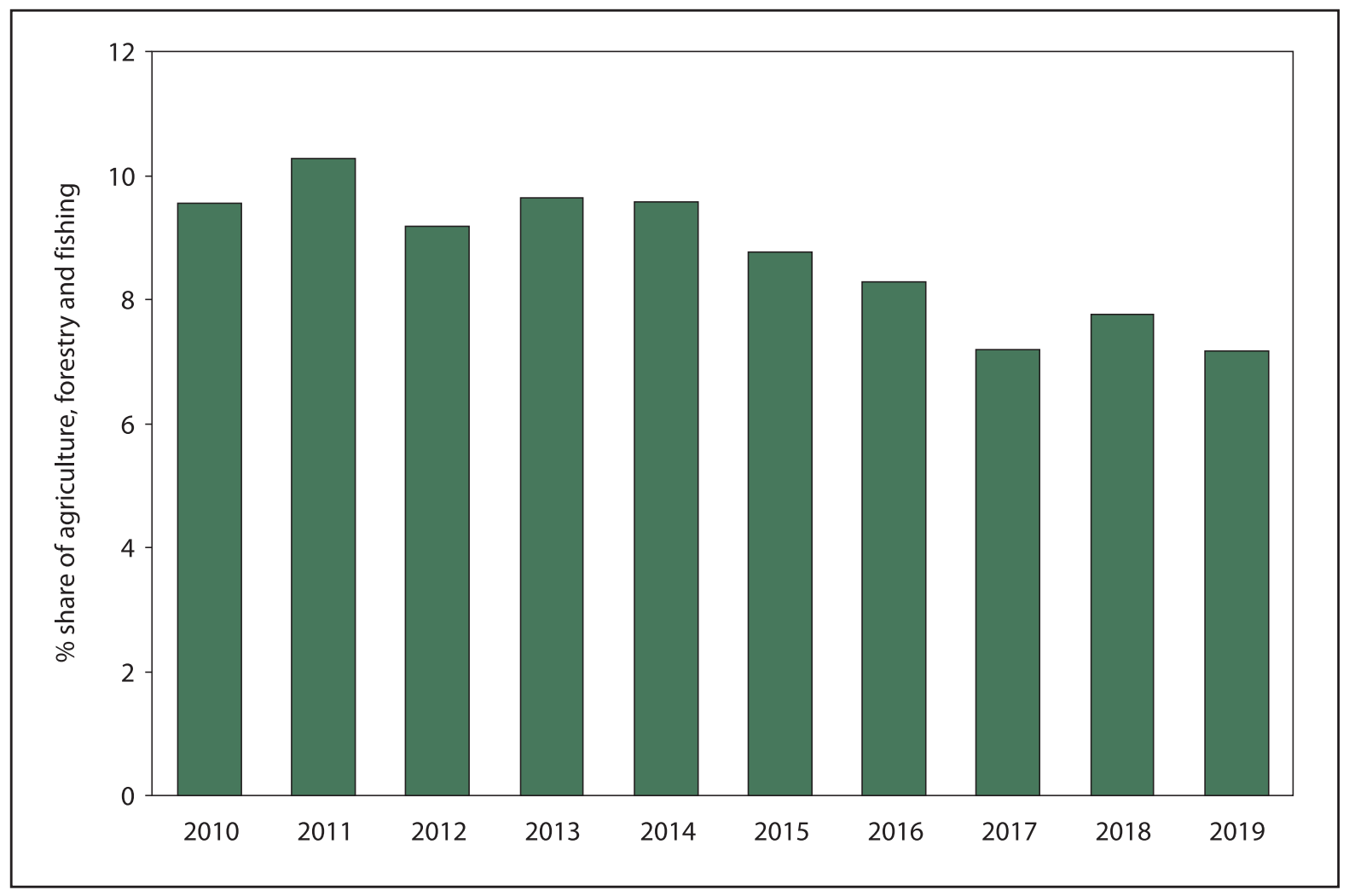

Fig. 3. Percentage share of agriculture in GDP of Georgia in 2010-2019

Source: own elaboration based on GEOSTAT data.

17 Final data for 2019 , i.e. after adjustment, will be published by Geostat in November 2020.
18 Average for the period $1999-2018$ is $0.9 \%$ of the total Georgian production in that period. 


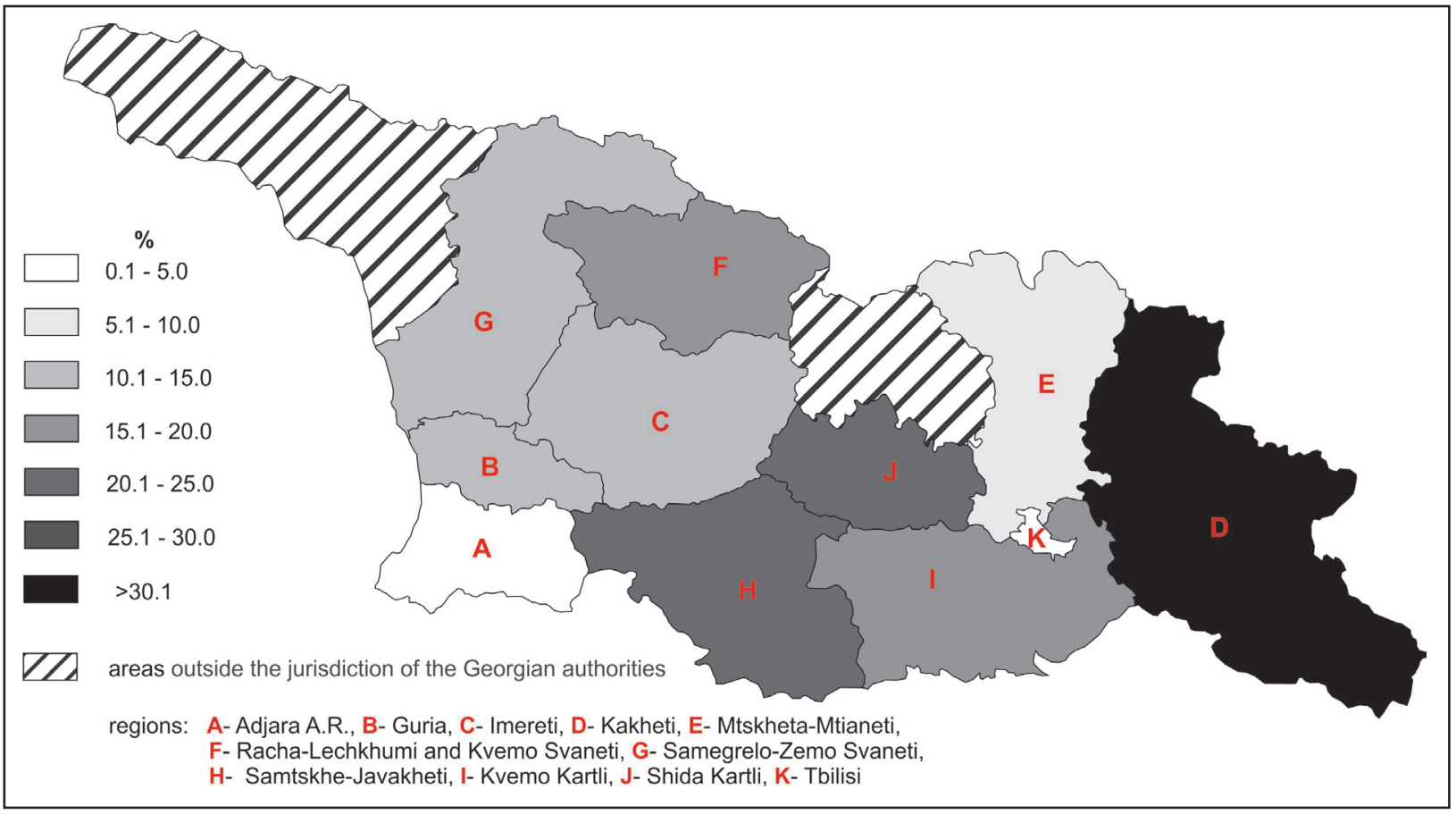

Fig. 4. Percentage share of agriculture in GDP of Georgian regions in 2018

Source: own elaboration based on GEOSTAT data.

2018 (GEL 1,068.3) this is a small amount. This indicates that most farmers produce for their own needs.

In 2018, the Georgian agricultural sector employed (including self-employed and hired employees) 659.2 thousand people, which accounted for $38.9 \%$ of all people employed in all sectors of the economy. The analysis of previous years shows that, like in the case of the percentage share of agriculture in the national GDP, this value is gradually decreasing. In 2014, the share of employment in agriculture in the total number of people employed amounted to approx. $46.6 \%$, and in $2005^{19}$ the share was $54.3 \%$. With regard to regions, the highest share of people employed in the agricultural sector in 2014 was recorded in Guria (72.2\% of total workforce) and RachaLechkhumi and Kvemo Svaneti (71.5\%). The least people working in agriculture in the studied period were recorded in Tbilisi (1.3\% of total workforce) and Adjara (43.4\%). Taking into account the population density of Tbilisi and the fact that it is a city included in Georgian statistics on a par with the regions, it should be emphasised that the small number of people employed in agriculture in this typically urbanised unit (the capital city) significantly affects the value of the above rate for the country. In fact, in all regions of Georgia (with the exception of Adjara)

19 The figures come from a recent publication Geostat on the Georgian labour market. In 2005, the sector consisted of agriculture, hunting and forestry (excluding fishing). more than $50 \%$ of people are employed in agriculture, hunting or forestry.

Data for the country on the size of unemployment suggest that the inhabitants of cities are statistically more likely to be affected by the problem of unemployment, where the average value of the unemployment rate in the years 1998-2018 amounted to $24.3 \%$. In rural areas, the average for the preceding years amounted to only $5.4 \%$.

A careful analysis of the results of general population and agricultural censuses confirmed the author of this study in the belief that the situation with regard to employment in rural areas is not in fact so positive. Given the type of employment, in 2018 only $23.8 \%$ of the total number of people working in cities were self-employed. In rural areas in the same year, there were 891.4 thousand employees, including 650.5 thousand self-employed people (approx. 73\%). Data from the last agricultural census (2014) show that in two regions, i.e. the mountain area of RachaLechkhumi and Kvemo Svaneti, and the coastal Guria, the share of self-employed persons with their own farms in the total number of employed amounted to almost $70 \%$.

Worrying is also the issue of significant disparities in the income of the residents of urban and rural areas. Wages of people working in agricultural occupations (mainly rural population) are the lowest compared to other sectors of the economy. Average earnings in the Georgian agricultural sector in 2018 amounted to $701 \mathrm{GEL}$, which accounted for $65.6 \%$ 
of the average earnings of the inhabitants of the country.

On the basis of the quoted statistical data, especially those related to the size of farms, employment and earnings it can be concluded that poverty in the rural areas of Georgia is a common concern.

\section{Summary}

Despite the numerous social and economic changes, Georgia is still in the process of transformation. An insufficient level of reform is reflected in strong regional disparities and persistent poor quality of life, particularly in the rural areas. Macroeconomic data (e.g. structure of national GDP, value of Foreign Direct Investment, production volume) suggest that agriculture is not currently the leading sector of the Georgian economy. The results of the extended analysis of the condition and the importance of the agricultural sector in the development process of the country and its regions have shown, however, that in the case of Georgia, it is particularly important, taking into consideration the population distribution of the country ( $41.3 \%$ of the total population) and its potential resulting from the natural conditions and the agrarian tradition.

The most important problems of the sector reported on the basis of the data also mentioned by the Georgian researchers and the authors of the national strategic documents include:

Low rate of growth compared to other sectors of the economy, marginal foreign investment in agriculture (approx. $1 \%$ of the total FDI), low value of production (only $1.2 \%$ of national production).

A small acreage of arable land, a low level of mechanisation of agriculture, outdated technical infrastructure; insufficient use of new technologies, in particular affecting the efficiency of production.

Predominance of small subsistence farming, the lack of universal registration of lands.

A high level of self-employment in agriculture (in many cases, taking into account the size of farms, de facto meaning unemployment), significant disparities in the earnings of those working in agricultural occupations in relation to the rest of the economy.

Inappropriate education of people employed in agriculture (the lack of technical preparation).

Analysis of statistical data broken down by region confirmed that the development Kakheti still to a large extent depends on the condition of its agriculture. Since the Soviet times, this region has played an important role in the functioning of the Georgian agricultural sector, especially due to the type of cultivation in its area (the unit is famous for grapevines). Another region strongly associated with the agricultural sector is Racha-Lechkhumi and Kvemo Svaneti. However, its specificity is different, mainly due to natural factors such as topography or climate. Agriculture there is more primitive and agricultural land is more fragmented. The level of agriculture directly affects the development of the entire region (it is one of the poorest administrative units). A similar situation can be observed in other typically agricultural regions of Georgia, e.g. Guria, which, like Racha-Lechkhumi and Kvemo Svaneti, on the one hand lacks large urban centers, which are the driving force of socio-economic development (a significant portion of the region's population lives in the countryside and works in agricultural occupations), on the other hand, its agricultural sector, which is in fact a key branch of the economy, is underdeveloped.

The most developed regions, i.e. Adjara and Tbilisi, are the least involved and dependent on the agricultural sector, and understandably the importance of agriculture in Tbilisi is marginal. Statistics show that the situation of rural areas in Adjara is different from those located in other regions, as evidenced by the largest positive natural increase rate or the dominance of permanent corps in the structure of agricultural land use.

In conclusion, because of the numerous problems and the fact that Georgia is dominated by the rural population, the Georgian agricultural sector requires a comprehensive reform based on the existing potential. As shown by historical conditions, despite the corrective actions taken, the sector is still struggling with many problems. On the national scale, agriculture does not play a significant role in shaping the country's economic growth, so it is not a leading branch of the Georgian economy, as evidenced by available macroeconomic statistics. However, there are regions for which it is the main source of income. Taking into account regional disparities, regional specialisations (key role of Kakheti for agriculture) and the continuing difficult economic situation of the rural population, it seems necessary to take the modernisation of the sector as a priority. Improving the quality of life of more than $40 \%$ of the population of Georgia will increase both the level of development of individual regions and the whole country.

\section{Acknowledgements}

Thestudy is the result of research project No. 2018/31/N/ HS4/00178 funded by the National Science Centre. 


\section{References}

Analysis of Regional Disparities in Georgia, 2016, Ministry of Regional Development and Infrastructure of Georgia, Tbilisi.

Bański J., 2006, Geografia polskiej wsi (Eng. Rural geography of Poland), PWE, Warszawa.

Bański J., 2007, Geografia rolnictwa Polski (Eng. Geography of Polish agriculture) PWE, Warszawa.

Bondyrev I., Davitashvili Z., Singh V., 2015, The Geography of Georgia. Problems and perspectives, Springer International Publishing, Cham.

Brodowski J., 2019, Gruzja po rewolucj iróż (Eng. Georgia after Rose Revolution), Księgarnia Akademicka, Kraków.

BTI 2020: Georgia, 2020, BTI Transformation Index, https:// bti-project.org/en/reports/country-dashboard-GEO.html (accessed 10 May 2020).

Chankseliani M., 2013, Rural Disadvantage in Georgian Higher Education Admissions: A Mixed-Methods Study, Comparative Education Review, 57(3), 424-456. doi: $10.1086 / 670739$

Dawitaj F.F. (ed.), 1972, Zwiq̨zek Radziecki. Gruzja (Eng. Soviet Union. Georgia), PWN, Warszawa.

Fuenfzig M., 2013, Regional Disparities in Georgia: Evidence from Microdata, MPRA Paper, 76694 University Library of Munich, Munich, https://mpra.ub.uni-muenchen. de/76694/1/MPRA_paper_76694.pdf (accessed 12 May 2020).

GEOSTAT, National Statistics Office of Georgia, Tbilisi, https:// www.geostat.ge/en (accessed 20 March 2020).

Gvindadze D., 2017, The Transformation of Georgia from 2004 to 2012. State building, Reforms, Growth and Investments, Palgrave Macmillan, Tbilisi.

Kharaishvili E., Erkomaishvili G., Chavleishvili M., 2015, Problems Faced by the Agricultural Sector and Agribusiness Development Strategy in Georgia, World Academy of Science, Engineering and Technology International Journal of Industrial and Systems Engineering, 9(11), 3833-3837.

Law of Georgia on General Education, 2005, Ministry of Education and Science of Georgia, https://matsne.gov.ge/ en/document/download/29248/56/en/pdf (accessed 17 March 2020).

Maryański A., 1987, Geografia ekonomiczna Zwiqzzku Radzieckiego (Eng. Economic Geography of USSR), PWE, Warszawa.

Mzhavanadze G., Saha D., 2016, The Exchange Rates of the Georgian Lari and the Armenian Dram in Comparison, 2014-2015, Technical Note [TN/01/2016], German Economic Team Georgia, ISET Policy Institute, Berlin-Tbilisi.

Papava V., 2013, Georgia's socio-economic development: Prospects over the medium term, [in:] Georgia-Abkhazia on the road to 2020. Discussion paper, International Alert, London.

Regional Development Programme of Georgia 2018-2021, 2017, Ministry for Regional Development and Infrastructure, https://mrdi.gov.ge/pdf/5d11c43dcd7cc.pdf/20182021\%20Regional\%20Development\%20Programme\%20 of\%20Georgia\%20\%28Unofficial\%20translation\%29.pdf (accessed 10 March 2020).
Rodriquez-Pose A., Hardy D., 2017, Firm competitiveness and regional disparities in Georgia, Geographical Review, 107(2), 384-411. doi: 10.1111/j.1931-0846.2016.12180.x

Rural Development Strategy of Georgia 2017-2020, 2017, Ministry of Agriculture of Georgia, http://enpard.ge/en/ wp-content/uploads/2015/05/Rural-Development-Strategy-of-Georgia-2017-2020.pdf (accessed 10 March 2020).

Seturi M., Todua T., 2019, Analysis of the Georgian tea brands, European Cooperation, 4(44), 7-14. doi: 10.32070/ ec.v4i44.59

The World Bank, https://www.worldbank.org (accessed 5 August 2020).

Tielidze L. (ed.), 2019, Geomorphology of Georgia, Springer International Publishing, Cham.

Welton G. (ed.), 2013, Comparative analysis of agriculture in the South Caucasus, UNDP Georgia, Tbilisi. 